\title{
Lipolytic bacteria and the dynamics of flavor production in Indonesian tempeh
}

\author{
NASWANDI NUR ${ }^{1, \boldsymbol{v}}$, ANJA MERYANDINI ${ }^{1}$, MAGGY THENAWIDJAJA SUHARTONO ${ }^{2}$, \\ ANTONIUS SUWANTO ${ }^{1, \text {,v }}$ \\ ${ }^{1}$ Department of Biology, Faculty of Mathematics and Natural Sciences, Institut Pertanian Bogor. Jl. Agatis, Kampus IPB Dramaga, Bogor 16680, West \\ Java, Indonesia. Tel./fax.: +62-251-8622833, ^email: naswandi.nur@gmail.com, ^^email: antoniussuwanto@gmail.com. \\ ${ }^{2}$ Department of Food Science and Technology, Faculty of Agricultural Technology, Institut Pertanian Bogor. Jl. Raya Dramaga, Kampus IPB Dramaga \\ Bogor 16680, West Java, Indonesia
}

Manuscript received: 17 June 2020. Revision accepted: 27 July 2020.

\begin{abstract}
Nur N, Meryandini A, Suhartono MT, Suwanto A. 2020 Lipolytic bacteria and the dynamics of flavor production in Indonesian Tempeh. Biodiversitas 21: 3818-3825. During the process of tempeh maturation, lipolytic bacteria become an integral part of tempeh and even have important roles in determining the quality of resulting tempeh. This study was conducted to examine correlation between lipolytic bacteria which were present in three tempeh samples i.e. CMG, EMP, RTI, and their roles in liberation of free fatty acid. Lipolytic bacteria were found in each tempeh sample which were approximately $0.1 \%$ of total bacterial population. CMG harbored the highest lipolytic bacterial population at $1.04 \times 10^{6} \mathrm{cfu} \mathrm{g}^{-1}$ followed by EMP at $2.88 \times 10^{5} \mathrm{cfu} \mathrm{g}^{-1}$, and RTI at $1.72 \times 10^{4} \mathrm{cfu}$ $\mathrm{g}^{-1}$. Tempeh aroma and texture showed strong correlation between the numbers of bacterial population during the period or stages of tempeh maturation. Moreover, we also found a unique correlation between dynamic of lipolytic population and aroma changes. Free fatty acid profiling indicates that lipolysis activity was presence during fermentation of tempe where each tempeh samples showed some differences in liberation of dominant free fatty acid. 16S rRNA sequencing from a hundred of lipolytic isolates was identified and classified as member of the phylum Proteobacteria, Firmicutes, and Actinobacteria, other isolates were classified as uncultured clone.
\end{abstract}

Keywords: 16 s rRNA, free fatty acid, GC-FID, lipolysis, tempeh

\section{INTRODUCTION}

Tempeh (originally written as tempe) is a traditional Indonesian fermented food produced by fermentation of soybeans using Rhizopus oligosporus (fungi: Zygomycotina). Tempeh has become an important part of the Indonesian (especially Javanese) diet for hundreds of years. In addition to being a source of proteins and lipids in a vegetarian diet, tempeh became of interest due to its interesting nutritional or functional properties. Nowadays, tempeh has become increasingly popular not only in Indonesia but also in many countries such as Japan, United States, Canada, Australia, and several countries in Western Europe. Indonesian tempeh is an ecosystem with high diversity of microorganisms (Barus et al. 2008). Besides $R$. oligosporus, the presence of the bacteria also plays important roles during tempeh fermentation processes. Some of these bacteria play a role in the development of flavor, aroma, nutrition, and the quality of the resulting tempeh (Hagedorn and Kaphammer 1994).

During the fermentation of soybeans, Citrobacter freundii and Klebsiella pneumoniae are essential in synthesis of vitamins B12 (Keuth and Bisping 1994), Micrococcus or Arthrobacter in the synthesis of isoflavones (Klus et al. 1993), while Rhizopus oligosporus plays role especially in hydrolysis of fats (Mienda et al. 2011). The enzymatic digestion of substrates caused a decrease in the amount of crude lipids, as lipids serve as the main source of energy for the lipolytic microorganisms. It leads to an increased amount of free fatty acids by $25-26 \%$ (Leitao et al. 1967; Astuti et al. 2000) and also to the development of characteristic flavor. So far, the lipolytic activity in tempeh was only reported as the result of the enzymatic activity of Rhizopus sp. or Mucor sp. However, we showed here that lipolytic microorganisms on tempeh are not only limited to molds, some bacteria associated with tempeh were also capable of producing lipases. Our study presented diversity of lipolytic bacteria and their potential roles in releasing free fatty acids during various stages of tempeh post-fermentation.

\section{MATERIALS AND METHODS}

\section{Description of the sampling}

Samples were collected from various tempeh producers in Bogor area, Indonesia. Tempeh was sampled in various incubation time, i.e. $12,24,48$, and 72 hours after tempeh was fully fermented. Tempeh samples should be split beans in compact mycelial mats, white or slightly gray, and has distinctive smell of fresh tempeh. Samples were collected under aseptic conditions using sterile airtight plastic to reduce the possibility of contamination during transfer to the laboratory for further analysis. Observation of the condition of tempeh was also carried out in several time periods after their peak maturation (fresh tempeh). The range of observations starts from $0,12,24,48$, and 72 
hours post-fresh tempeh. Physical conditions of tempeh which include texture of tempeh (solid, soft, or slimy), appearance of soybean seeds (color and texture) which composed them, physical conditions of hyphae (color, density, and sporulation) that bind tempeh and aroma changes (fresh or unpleasant) were observed.

\section{Culture media}

Plate count agar was used to enumerate the total bacterial population associated with tempeh. Lipase producing bacteria were identified in Rhodamine B lipase agar plate (Kumar et al. 2012). This media consists of three components i.e. Base medium, lipid emulsion, and $0.1 \%$ Rhodamine B solution. Luria Bertani (LB) was used as base medium contains $1 \%(\mathrm{w} / \mathrm{v})$ tryptone, $0.5 \%(\mathrm{w} / \mathrm{v})$ yeast extract, $0.5 \%(\mathrm{w} / \mathrm{v}) \mathrm{NaCl}$, and $2 \%(\mathrm{w} / \mathrm{v})$ bacto agar. lipid emulsion consists of extra virgin olive oil and polyvinyl alcohol 2\% with a proportion of 1: $3(\mathrm{v} / \mathrm{v}) .0 .1 \%$ Rhodamine B solution $(1 \% \mathrm{w} / \mathrm{v})$ was added as an indicator of free fatty acid (Kouker and Jaeger 1987). 50 ppm cycloheximide was added to suppress the growth of fungi.

\section{Total bacteria and lipolytic bacteria populations}

Each $25 \mathrm{~g}$ tempeh samples were homogenized with 225 $\mathrm{mL}$ of sterile saline $(0.85 \% \mathrm{NaCl})$ for five minutes to obtain a dilution of $1: 10\left(10^{-1}\right)$. The slurry was serially diluted ( $1 \mathrm{~mL}$ in $9 \mathrm{~mL}$ ) to enumerate colonies on plate. Enumeration was conducted on culture media as described previously. Total population of bacteria on plate count agar (PCA) was observed directly based on the number of viable cells formed (Cappuccino and Sherman 2001), while the number of lipolytic bacterial populations was observed based on the number of colonies forming a glowing zone when observed through UV transilluminator. The incubation conditions for calculating the number of colonies on both media were carried out aerobically for 24 and 48 hours at $37( \pm 1)^{\circ} \mathrm{C}$.

\section{Analysis of fatty acid methyl esters using GC-FID}

One gram of tempeh was homogenized with $9 \mathrm{ml}$ of $\mathrm{dH}_{2} \mathrm{O}$ to obtain tempeh slurry. As much as $100 \mathrm{mg}$ of tempeh slurry was dissolved in 4: $1(\mathrm{v} / \mathrm{v})$ methanolbenzene. Esterification was done by adding $200 \mu \mathrm{l}$ of acetyl chloride slowly while being shaken with vortex. The solution formed in the tube was incubated for 60 minutes at a temperature of $100^{\circ} \mathrm{C}$ by treating the vortex every 15 minutes incubation interval. The tube was cooled at $4^{\circ} \mathrm{C}$ for 10 minutes, then $5 \mathrm{ml}$ of a $6 \% \mathrm{~K}_{2} \mathrm{CO}_{3}$ solution was added slowly to stop the reaction and neutralize the solution. The evaporation rotary was carried out for 15 minutes before adding $4 \mathrm{~mL}$ hexane and centrifuge at $3000 \times \mathrm{rpm}$ for 10 minutes and organic phase separation (Carvalho et al. 2012). The analysis was carried out by injecting $2 \mu \mathrm{l}$ of fatty acid esterification into gas chromatography (Agilent Technologies 6890) equipped with Flame Ionizer Detector (FID), HP-Innowax, capillary column, $30 \mathrm{~m} \times 0.250 \mathrm{~mm}$ coated with $0.25 \mu \mathrm{m}$ film. The carrier gas used was hydrogen with a split ratio of $8: 1$. The injector temperature and detector were set at $250^{\circ} \mathrm{C}$. the column temperature was maintained at $60^{\circ} \mathrm{C}$ for 30 seconds then raised to $210^{\circ} \mathrm{C}$ for 15 minutes.

\section{Identification of dominant lipase producing isolates}

Amplification of the 16S rRNA gene was carried out through direct PCR techniques (Woodman et al. 2016). A small amount of bacterial colonies and controls were directly amplified with $0.5 \mu \mathrm{M}$ primers of $63 \mathrm{f}$ (5'CAGGCCTAACACATGCAAGTC-3') and 1387r (5'GGGCGGWGTGTACAAGGC-3') (Marchesi et al. 1998), $5 \mu \mathrm{l}$ go-Taq Green master mix (Promega), 0.5 $\mu \mathrm{L}$ DMSO, and $2.4 \mu \mathrm{lddH} 2 \mathrm{O}$. Amplification conditions for both PCRs were as follows: 7 minutes at $94^{\circ} \mathrm{C}$ to denature the DNA, followed by 30 cycles of denaturation at $94^{\circ} \mathrm{C}$ for 45 seconds, primer annealing at $55^{\circ} \mathrm{C}$ for 60 seconds and strand extension at $72^{\circ} \mathrm{C}$ for 90 seconds, a final extension at $72^{\circ} \mathrm{C}$ for 15 minutes on a thermal cycler. PCR products were separated on a $1 \%$ agarose gel and DNA bands were visualized with ethidium bromide. The amplified PCR product was gel purified using the QIAGEN gel extraction kit. Total of $100 \mathrm{ng} / \mu \mathrm{l}$ concentration of $16 \mathrm{~S}$ rRNA amplified product was used for the sequencing with the $63 \mathrm{~F}$ primer by the contract research service. The sequences thus obtained were compared with the NCBI database through BLAST searches (http://blast.ncbi.nlm.nih.gov/Blast.cgi) using the algorithm BLASTn program.

\section{Data analysis}

Experiments were performed in five replicates and the results were analyzed statistically. The dynamics of the total bacteria and lipolytic bacterial population value expressed as log cfu per gram of sample at each observation stage (12 hours, 24 hours, 48 hours and 72 hours) for these three kinds of tempeh (CMG, EMP, and RTI). The results were expressed as the mean \pm SD for each group of observations. Statistical differences $(p<$ $0.05)$ were evaluated using a one-way analysis of variance (ANOVA) followed by Fisher's Least Significant Difference (LSD) test. Data analyzed using statistical applications Minitab 16.2.4 software (Minitab Inc. Pennsylvania, US).

\section{RESULTS AND DISCUSSION}

\section{Survey and observation of physical conditions}

Samples were collected from three different tempeh producers in Bogor, Indonesia, those three producers were designated as CMG, EMP, and RTI. All three kinds of tempeh produced using the same types of soybean, starter, and method of processing. CMG tempeh producers represent traditional tempeh production, namely processing of Pekalongan tempeh and having the highest levels of microbial load. The processing of Pekalongan tempeh is a method of processing tempeh which only through one step of soaking (acidification) of raw soybean before being boiled and added starter (Barus et al. 2008). EMP tempeh producers also represent processing tempeh which is similar to CMG and have moderate levels of microbial load 
(not as high as the CMG). RTI tempeh is the cleanest or most "hygienic". These tempeh were processed in a rather modern way through stainless steel vats and environment with low microbial loads. All samples were collected separately from each producer to minimize the exchange of microbiota between tempeh samples.

The initial physical condition of tempeh from all samples showed white mycelia without sporulation and seems strongly bind the soybeans (Gunawan-Puteri et al. 2015). Physical condition changes (mycelia and soybean) most rapidly in CMG after 24 hours post-fermentation, followed by EMP at 48 hours and RTI at 72 hours (Table 1). The level of cleanliness during tempeh production was assessed to be positively correlated with the shelf life of tempeh at ambient temperature. Cleanliness during tempeh processing has a profound effect on the number of microorganisms that successfully invaded tempeh. Some microorganisms play role in the process of food spoilage and caused tempeh shelf life only last for few days (Babu et al. 2009). The initial aroma of tempeh (fresh tempeh) was defined as fresh aroma, showing the distinctive (pleasant) smell of cooked soybeans with a slight aroma of molds (Shurtleff and Aoyagi 1979). Another aroma was sharper and less pleasant (unpleasant) was defined as semangit (Utami et al. 2015). CMG was kind of tempeh with the fastest aroma change, which becomes semangit after 48 hours post-sampling, followed by EMP after 72 hours while RTI does not show a significant aroma change during the observation (Table 1).

\section{Population dynamics of total bacteria and lipolytic bacteria}

Total bacterial and lipolytic bacteria populations were enumerated after plate cultured for 24 hours and 48 hours at $37^{\circ} \mathrm{C}$ (Figure 1). Number of forming colonies was expressed in densities number of bacteria contained in each gram of tempeh (cfu $\mathrm{g}^{-1}$ ). The fluorescent halos at rhodamine media were caused by reaction between the fluorescent dye from rhodamine B with the free fatty acids from hydrolysis of fats (olive oil) by lipolytic bacteria (Figure 1). The brightness and size of the halo zone surrounding the colony expressed lipolytic ability.

Enumeration of total bacteria populations associated with tempeh was conducted manually. Enumeration techniques were carried out by identifying and calculating the entire viable growing colonies on culture media. PCA is free from selective supplements and relatively rich in nutrients, making it ideal for most bacteria to grow.

CMG showed increase in number of total bacterial populations. Total number of bacterial populations after 12 hours was $2.31 \times 10^{9} \mathrm{cfu} \mathrm{g}^{-1}$. Increasing the total bacterial population of CMG increase gradually after 24,48 and 72 hours were $3.96 \times 10^{9} \mathrm{cfu} \mathrm{g}^{-1}, 6.22 \times 10^{9} \mathrm{cfu} \mathrm{g}^{-1}$, and $1.02 \times$ $10^{10} \mathrm{cfu} \mathrm{g}^{-1}$, respectively (Table 2 ). The pattern of EMP population dynamics showed similar pattern implied by $\mathrm{CMG}$, the difference between both tempeh was population density of CMG significantly greater than EMP. After 12 hours of observation, the population density of EMP was $9.78 \times 10^{8} \mathrm{cfu} \mathrm{g}^{-1}$ or two times lower than CMG was $2.31 \times$ $10^{9} \mathrm{cfu} \mathrm{g}^{-1}$ at the same observation period. In the next 24 hours, EMP population was running slow (not significantly different, $\mathrm{p}<0.05$ ), it was $1.01 \times 10^{9} \mathrm{cfu} \mathrm{g}^{-1}$. Rapid growth of population density increased significantly after 48 hours was $3.26 \times 10^{9} \mathrm{cfu} \mathrm{g}^{-1}$ and $6.92 \times 10^{9} \mathrm{cfu} \mathrm{g}^{-1}$ after 72 hours. RTI showed a similar dynamic pattern with both other kinds of tempeh, but the density level of bacteria population on it was lower than CMG or EMP (Figure 2). Total bacteria population on RTI after 12 hours was $4.04 \times$ $10^{5} \mathrm{cfu} \mathrm{g}^{-1}$ or 1000 -fold lower than EMP or CMG. Total bacteria on RTI increased become $5.72 \times 10^{5} \mathrm{cfu} \mathrm{g}^{-1}$ after 24 hours, $8.54 \times 10^{5} \mathrm{cfu} \mathrm{g}^{-1}$ after 48 hours, and $1.26 \times 10^{6}$ $\mathrm{cfu} \mathrm{g}^{-1}$ after 72 hours, respectively.

Table 1. Changes in aroma and some physical properties of tempeh samples with increase in storage time.

\begin{tabular}{|c|c|c|c|c|c|c|c|c|c|c|}
\hline \multirow{2}{*}{\multicolumn{2}{|c|}{$\begin{array}{c}\text { Time of } \\
\text { observation }\end{array}$}} & \multicolumn{3}{|c|}{ Mycelia } & \multicolumn{2}{|c|}{ Soybeans } & \multicolumn{3}{|c|}{ Consistency } & \multirow[t]{2}{*}{ Aroma } \\
\hline & & color & texture & spore & color & texture & compact & soft & slimy & \\
\hline \multirow{5}{*}{$\sum_{U}^{U}$} & $0 \mathrm{hr}$ & clean-white & dense & - & clear & chewy & + & - & - & fresh tempeh \\
\hline & $12 \mathrm{hr}$ & clean-white & dense & - & clear & chewy & + & - & - & fresh tempeh \\
\hline & $24 \mathrm{hr}$ & grey-white & loose & + & yellowish & slightly tender & - & + & - & fresh tempeh \\
\hline & $48 \mathrm{hr}$ & yellowish & loose & + & yellowish & slightly tender & - & + & + & semangit \\
\hline & $72 \mathrm{hr}$ & yellowish & loose & + & brownish & tender & - & + & + & semangit \\
\hline \multirow{5}{*}{$\sum_{I I}^{Q}$} & $0 \mathrm{hr}$ & clean-white & dense & - & clear & chewy & + & - & - & fresh tempeh \\
\hline & $12 \mathrm{hr}$ & clean-white & dense & - & clear & chewy & + & - & - & fresh tempeh \\
\hline & $24 \mathrm{hr}$ & grey-white & dense & - & yellowish & chewy & + & - & - & fresh tempeh \\
\hline & $48 \mathrm{hr}$ & grey-white & loose & + & yellowish & slightly tender & - & + & - & fresh tempeh \\
\hline & $72 \mathrm{hr}$ & yellowish & loose & + & yellowish & slightly tender & - & + & + & semangit \\
\hline \multirow{5}{*}{$\vec{E}$} & $0 \mathrm{hr}$ & clean-white & dense & - & clear & chewy & + & - & - & fresh tempeh \\
\hline & $12 \mathrm{hr}$ & clean-white & dense & - & clear & chewy & + & - & - & fresh tempeh \\
\hline & $24 \mathrm{hr}$ & clean-white & dense & - & clear & chewy & + & - & - & fresh tempeh \\
\hline & $48 \mathrm{hr}$ & clean-white & dense & + & yellowish & chewy & + & - & - & fresh tempeh \\
\hline & $72 \mathrm{hr}$ & grey-white & dense & + & yellowish & slightly tender & + & - & - & fresh tempeh \\
\hline
\end{tabular}

Note: Semangit (language: Javanese) refers to over fermented tempeh with pungent and unpleasant odor (Hassanein et al. 2015). 


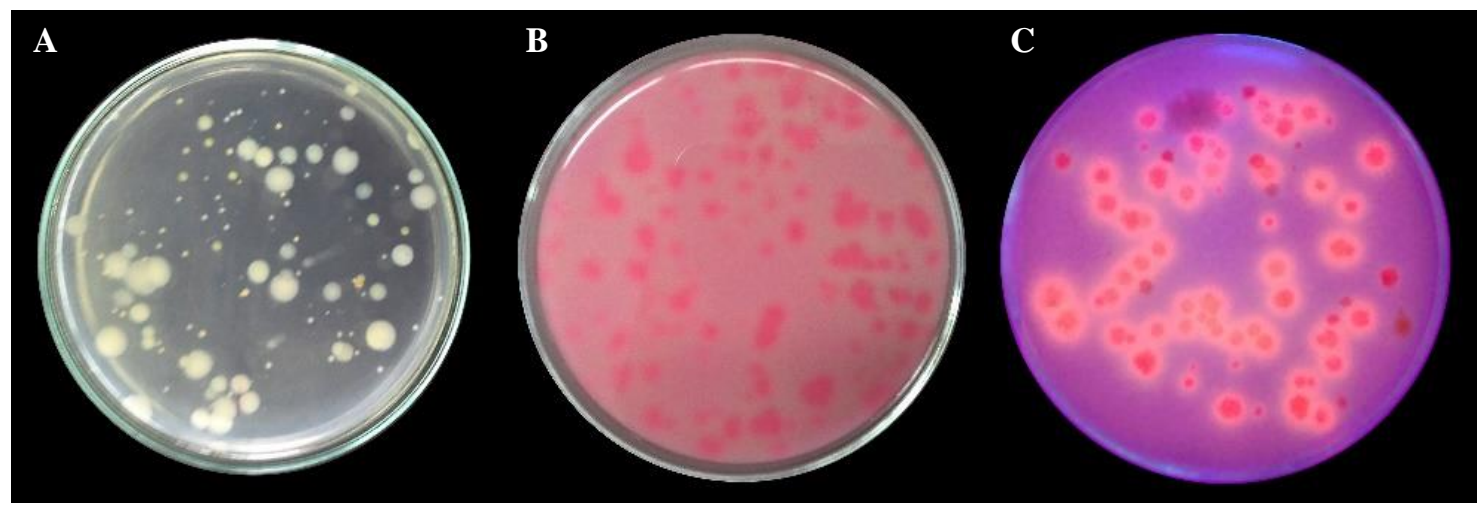

Figure 1. Screening of total bacterial population on agar plate count media (A) and lipolytic populations on rhodamine media without ultraviolet irradiation (B) and with ultraviolet irradiation (C), red colonies and fluorescence around the colonies indicate lipolytic activity. All plates were incubated for 48 hours at $37^{\circ} \mathrm{C}$.

CMG lipolytic population at first 12 hours was $1.04 \times$ $10^{6} \mathrm{cfu} \mathrm{g}^{-1}$ then declined to $7.7 \times 10^{5} \mathrm{cfu} \mathrm{g}^{-1}$ after 24 hours observation. After 48 hours, the population density gradually increased to $1.18 \times 10^{6} \mathrm{cfu} \mathrm{g}^{-1}$ and reached $1.74 \times$ $10^{6} \mathrm{cfu} \mathrm{g}^{-1}$ after 72 hours (Table 3). Similar pattern also showed by EMP. Population density on EMP after 12 hours was $2.88 \times 10^{5} \mathrm{cfu} \mathrm{g}^{-1}$. Those numbers subsequently decreased after 24 and 48 hours were $2.18 \times 10^{5} \mathrm{cfu}^{-1}$ and $1.88 \times 10^{5} \mathrm{cfu} \mathrm{g}^{-1}$ respectively. Then after 72 hours, the population density of EMP rose to $4.72 \times 10^{5} \mathrm{cfu} \mathrm{g}^{-1}$. Since the population density was very low, RTI showed a totally different pattern from the previous two kinds of tempeh (Table 3). At first 12 hours of observation, the lipolytic population density was $1.5 \times 10^{4} \mathrm{cfu} \mathrm{g}^{-1}$, it was 100 -fold lower than $\mathrm{CMG}$ or EMP. Population density significantly increased to $2.82 \times 10^{5} \mathrm{cfu} \mathrm{g}^{-1}$ after 24 hours then relatively constant at $2.8 \times 10^{5} \mathrm{cfu} \mathrm{g}^{-1}$ and $3.06 \times 10^{5} \mathrm{cfu} \mathrm{g}^{-1}$ after 48 and 72 hours respectively.

\section{Correlation between population dynamics of lipolytic bacteria with tempeh aroma}

The initial odor of tempeh (fresh aroma) described as a nutty, cheesy, mushroomy, or yeast-like freshly baked bread (Shurtleff and Aoyagi 1979). Another odor observed during the observation, unpleasant and pungent odor defined as "semangit" aroma (Shurtleff and Aoyagi 1979). CMG is a kind of tempeh with fastest aroma changes into semangit after 48 hours, followed by EMP after 72 hours and the RTI not showed aroma changing into semangit all overtime of observation. Correlation between dynamics of lipolytic populations and aroma changes on tempeh just observed in CMG and EMP tempeh. That tempeh showed two distinguished phases were population declining phase and population increasing phase. lipolytic populations of CMG keep declined for the first 24 hours then swiftly rose after 24 hours until the rest of observation while EMP declined longer in the first 48 hours then start growing for the rest of observation. When the tren of lipolytic dynamics shifted from declining to increased, tempeh aroma also shifted from fresh aroma to semangit aroma. Since RTI did not show any significant aroma changes, so the correlation between aroma and its lipolytic dynamics cannot be concluded.

\section{Analysis of free fatty acid content with the CG-FID method}

Free fatty acids profile contained in tempeh can be used as an indication of the presence of lipolytic activity. A method for selectively determining free fatty acids (FFA) in tempeh was investigated and optimized using gas chromatography after esterification of the target sample to their corresponding fatty acid methyl esters (FAMEs). The GC-FID analysis gives an overview of the overall composition of a sample.

The free fatty acid released by each tempeh was almost evenly distributed in CMG, EMP, and RTI. The profile of fatty acid compounds in all three samples was dominated by a group of long-chain free fatty acids (C16-C18). The most dominant free fatty acids were observed in all kinds of tempeh samples were linoleic acid with the largest proportion (3.51-10.29\%) followed by oleic acid (1.44$3.96 \%)$, palmitic acid (0.91-2.53\%), acid $\gamma$-linolenic acid $(0.31-1.24 \%)$, linolenic acid (0.27-0.92\%) and stearic acid (0.32-0.78\%), respectively. CMG harbored lowest free fatty acid content than the other two kinds of tempeh. Free fatty acid content released by EMP and RTI not significantly different.

Profile of free fatty acids composition in CMG and EMP showed consistency in patterns for all dominant FFA, while RTI showed inconsistency in releasing of free fatty acids (Figure 2). The consistency of fatty acid dynamics indicates lipolytic ability with extensive substrate recognition. Lipase activity in CMG and EMP was able to break almost all types of available fatty acids, although the highest activity in EMP tempeh was more significant in $\gamma$ linoleic (Figure 2.D) and stearic acids (Figure 2.F). RTI appeared more active breaks linoleic acid than others (Figure 2E.). 
A

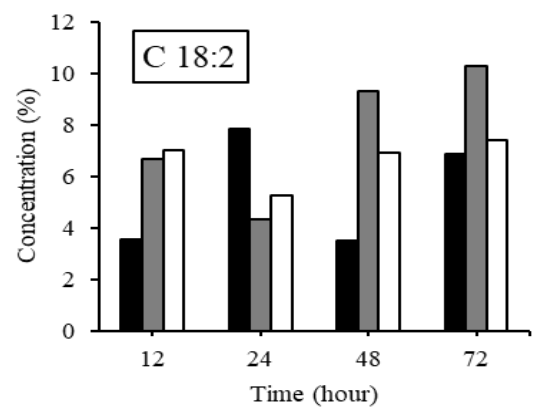

C

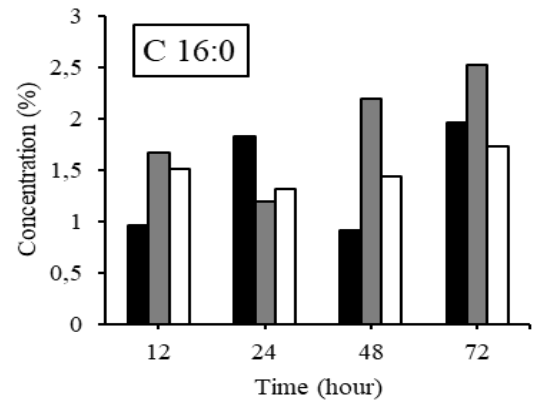

$\mathbf{E}$

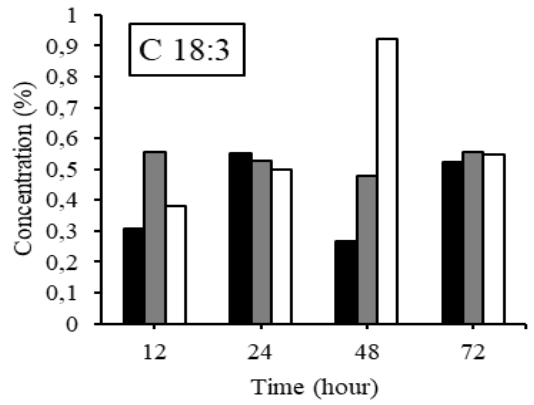

CMG

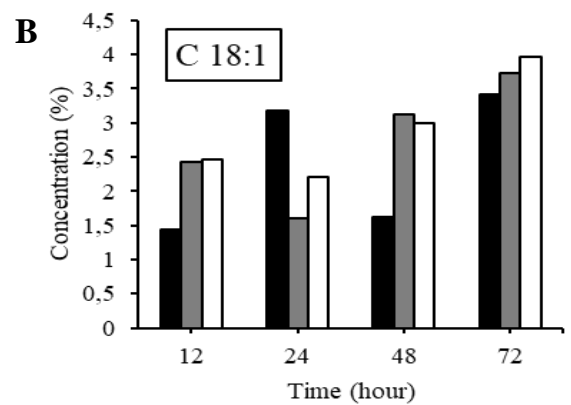

D

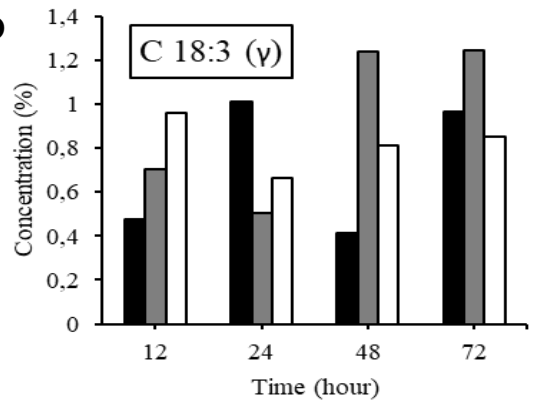

F

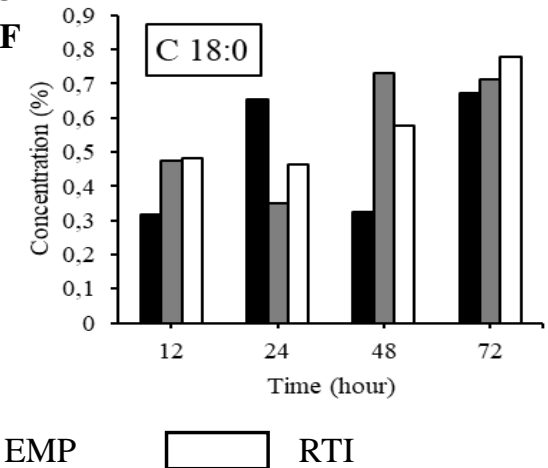

Figure 2. Changes in composition of dominant free fatty acid of tempeh. A. Linoleic acid (C18: 2); B. oleic acid (C18: 1); C. Palmitic acid (C16: 0); D. $\gamma$-Linolenic acid (C18: 3); E. linolenic acid (C18: 3); and F. stearic acid (C18: 0). Time in the graph shows the age of tempeh when GC-FID analysis was carried out.

\section{Molecular identification of lipolytic bacteria associated with tempeh}

About two hundred amplicons of 16S rRNA gene from lipolytic bacteria were analyzed to obtain an understanding of the diversity of the lipolytic bacterial community associated with tempeh. 16S rRNA gene is affiliated with at least three phylum-level groups were Proteobacteria, Firmicutes, and Actinobacteria. Members of these three phyla comprised an average of $95 \%$ of the tempeh lipolytic community. A total of 200 single colonies were isolated from various observation time frames in each sample, the genera diversity were almost identical in all kinds of tempeh (Figure 3). All lipolytic bacteria showed dominance of Proteobacteria (> 50\%). Beside Proteobacteria, lipolytic bacteria were also identified from the phylum Firmicutes, Actinobacteria, and uncultured clones. The group of lipolytic bacteria from Proteobacteria was subdivided into nine genera; Serratia, Morganella, Moraxella, Pseudomonas, Klebsiella, Raoultella, Proteus, Citrobacter, and Acinetobacter. Firmicutes were dominated by two genera Bacillus and Staphylococcus, while Actinobacteria were represented by Micrococcus, Kochuria, Barrientiisomonas, and Salinibacterium (Figure 4).

CMG and EMP (Figures 4.A-B) showed similarity of lipolytic bacteria distribution during the observation. Proportion of Proteobacteria and gram-positive bacteria (Firmicutes and Actinobacteria) was 60:40. In contrast to the Proteobacteria proportion in RTI (Figure 4.C) which were under $50 \%$. Serratia, Moraxella, and Klebsiella were found in almost every observation point in all kinds of samples. Bacillus, Staphylococcus, and Micrococcus are the genus that dominated the group of gram-positive bacteria found in all samples. 
Table 2. Enumeration of total bacteria population on PCA medium. Colonies were enumerated from various time after sampling, incubated on agar plate at $37^{\circ} \mathrm{C}$ for 48 hours.

\begin{tabular}{cccc}
\hline $\begin{array}{c}\text { Observation } \\
\text { (hour) }\end{array}$ & CMG & EMP & RTI \\
\cline { 2 - 4 } & $2.31 \times 10^{9} \pm 7.65 \times 10^{7}$ & $9.78 \times 10^{8} \pm 5.26 \times 10^{7}$ & $4.04 \times 10^{5} \pm 3.36 \times 10^{4}$ \\
12 & $3.96 \times 10^{9} \pm 2.77 \times 10^{8}$ & $1.02 \times 10^{9} \pm 7.30 \times 10^{7}$ & $5.72 \times 10^{5} \pm 2.86 \times 10^{4}$ \\
48 & $6.22 \times 10^{9} \pm 2.59 \times 10^{8}$ & $3.26 \times 10^{9} \pm 1.82 \times 10^{8}$ & $8.54 \times 10^{5} \pm 3.44 \times 10^{4}$ \\
72 & $1.02 \times 10^{10} \pm 4.06 \times 10^{8}$ & $6.92 \times 10^{9} \pm 2.39 \times 10^{8}$ & $1.27 \times 10^{6} \pm 2.39 \times 10^{4}$ \\
\hline
\end{tabular}

Table 3. Enumeration of lipolytic bacteria population on Rhodamine B medium. Colonies were enumerated from various time after sampling, incubated at $37^{\circ} \mathrm{C}$ for 48 hours

\begin{tabular}{cccc}
\hline $\begin{array}{c}\text { Observation } \\
\text { (hour) }\end{array}$ & CMG & cfu g-1 & RTI \\
\cline { 2 - 4 } & $1.04 \times 10^{6} \pm 5.32 \times 10^{4}$ & $2.88 \times 10^{5} \pm 3.83 \times 10^{4}$ & $1.72 \times 10^{4} \pm 8.37 \times 10^{2}$ \\
24 & $7.70 \times 10^{5} \pm 7.48 \times 10^{4}$ & $2.18 \times 10^{5} \pm 2.59 \times 10^{4}$ & $2.82 \times 10^{4} \pm 1.30 \times 10^{3}$ \\
48 & $1.18 \times 10^{6} \pm 4.82 \times 10^{4}$ & $1.88 \times 10^{5} \pm 2.17 \times 10^{4}$ & $2.80 \times 10^{4} \pm 2.00 \times 10^{3}$ \\
72 & $1.74 \times 10^{6} \pm 7.19 \times 10^{4}$ & $4.92 \times 10^{5} \pm 3.96 \times 10^{4}$ & $3.06 \times 10^{4} \pm 1.67 \times 10^{3}$ \\
\hline
\end{tabular}

So far, most members of the phylum Proteobacteria are known to have lipolytic properties, their produce lipase enzymes that are either extracellularly secreted or remain stored in cells as intracellular proteins (Jarvis et al. 1997). Beside Proteobacteria, lipolytic bacteria also identified as phylum Firmicutes, Actinobacteria, even uncultured clones. The group of lipolytic bacteria from the Proteobacteria was subdivided into nine genera; Serratia, Morganella, Moraxella, Pseudomonas, Klebsiella, Raoultella, Proteus, Citrobacter, and Acinetobacter. Firmicutes were dominated by two genera Bacillus and Staphylococcus, while Actinobacteria by Micrococcus, Kochuria, Barrientiisomonas, and Salinibacterium (Figure 4).

Tempeh CMG and EMP (Figure 4.A-B) were showed similarity of lipolytic bacteria distribution during the observation. Proportion of Proteobacteria and grampositive bacteria (Firmicutes and Actinobacteria) was share ratio reaches 60:40. Contrast to the Proteobacteria proportion in RTI (Figure 4.C) which were under $50 \%$. Serratia, Moraxella, and Klebsiella are genus from Proteobacteria which were found at almost every observation point in all kinds of samples. Bacillus, Staphylococcus, and Micrococcus are the genera that dominated the group of gram-positive bacteria were found in all samples.

\section{Discussion}

Lipolytic bacteria present in tempeh might contribute to decomposition of triglyceride compounds in soybean. The more lipolytic bacteria involved, more lipase enzymes that work in releasing free fatty acids. In some cases, the lipolytic ability of a bacteria can run as fast as metabolic ability, so not all fatty acids released accumulate in the environment. The high population of bacteria in CMG resulted in the amount of free fatty acids that detected low during the observation. Despite a large number of total bacterial populations in $\mathrm{CMG}$, The bacteria themselves might utilize all types of nutrients including free fatty acids released during the lipolysis processes. EMP harbored a high population of lipolytic bacteria, but still contain high free fatty acid. RTI tempeh is the opposite of CMG, it contained the lowest population. Population size in RTI caused nutrients absorption to run differently. The bacterial in RTI will use carbohydrates as the most important source of nutrition before switching to using the available free fatty acids.

The proportion of free fatty acid in tempeh appears to be similar to the amount of soybean triglycerides. Since the quantity of free fatty acids and fatty acid methyl ester referable for food quality (Christen and López-Munguía 1994; Olivares et al. 2011), then free fatty acids released during lipolysis contribute directly to the taste of fermented foods. Microorganisms that play a role in the hydrolysis of free fatty acids or fatty acid methyl ester automatically became essential in flavor development. Lipolytic bacteria population in CMG and EMP was very high caused aroma changes very quickly while the aroma in RTI was changed very slow. Aroma is known to relate to sensory impressions due to volatile odorant. Free fatty acid or fatty acid methyl ester is an essential part of the aroma (Ritvanen et al. 2005). Besides being strong flavor compounds, free fatty acid is more susceptible to oxidation than esterified fatty acid (Nawar 1996). Lipid oxidation is known as one of the major causes of food spoilage. Lipid oxidation generally does not occur too much in fermented foods, this is due to the low redox potential and the presence of the natural antioxidants (Fox and Wallace 1997; McSweeney and Sousa 2000). In other hand, enzymatic hydrolysis of triacylglycerides into fatty acids and glycerol, mono, or diacylglyceride (lipolysis) are very significant in influencing the amount of fatty acids released. But in this study, there is no strong enough evidence to state that the aroma changes that occur in tempeh occur due to lipolysis 
activity alone. Compared to the effects of lipolysis activity, proteolytic activity can play a greater role in aroma changes. Polyunsaturated fatty acids are very susceptible to oxidation, which leads to various unsaturated aldehydes formation that greatly affect taste and aroma, more often defined as oxidative rancidity (Fox et al. 2000), meanwhile, proteolysis will produce unpleasant aroma changes (Olivares et al. 2011) as it is commonly found in tempeh semangit.

It was explained earlier that from about 200 isolates that were successfully identified to the genus level, almost all of them were verified and characterized for their lipase properties. Serratia marcescens isolated from fresh milk has been reported to show extracellular lipase production with a molecular weight of about $52 \mathrm{kDa}$, classified as a psychotropic lipase and optimum in the range of $\mathrm{pH} 8.0$ (Abdou 2003). Long before, Feller et al. (1991) succeeded in catalyzing lipase produced by Moraxella of Antarctic
TA144 with criteria similar to $S$. marcescens except that the molecular weight was around $47 \mathrm{kDa}$ and the ability to maintain lipolytic activity at almost $0^{\circ} \mathrm{C}$. Alkaline lipases were also successfully identified by Gunasekaran et al. (2006), this lipase was produced by Citrobacter freundii IIT-BT L139 with optimum conditions at $\mathrm{pH} 9.0$ and temperature $40^{\circ} \mathrm{C}$. Snellman et al. (2002) have also identified a type of extracellular lipase from the LipA group extracted from Acinetobacter sp. RAG-1 with optimum conditions at $\mathrm{pH} 9.0$ and temperature of $55^{\circ} \mathrm{C}$. Proteus mirabilis (Korman and Bowie 2012) became a bacterium with the most complete lipase characterization among all the lipolytic bacteria from Proteobacteria phyla identified in this study. Lipase from Proteus belongs to the class of psychotropic lipases which are incorporated in the subfamily lipase I.1 and have been comprehensively characterized to the crystal structure of its protein.
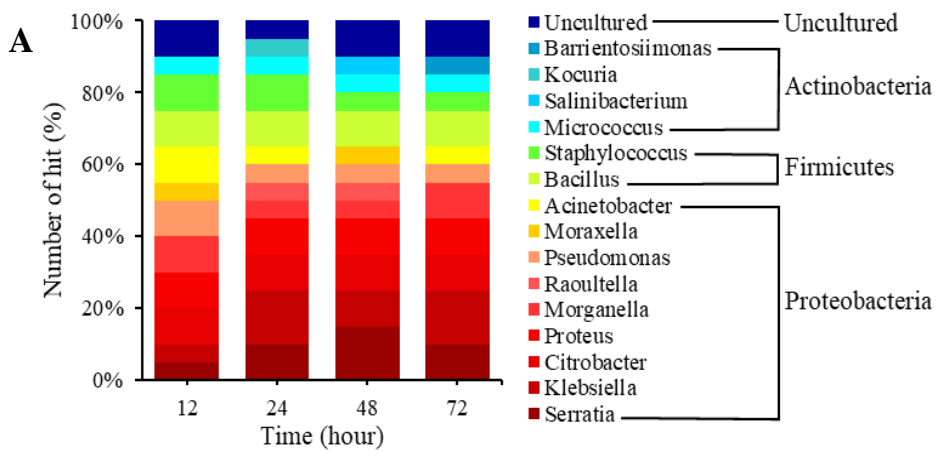

$\mathbf{B}$
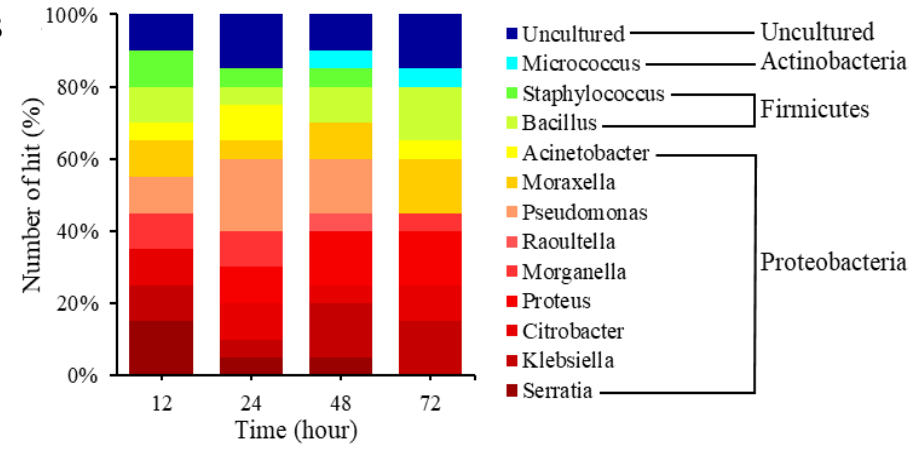

$\mathbf{C}$

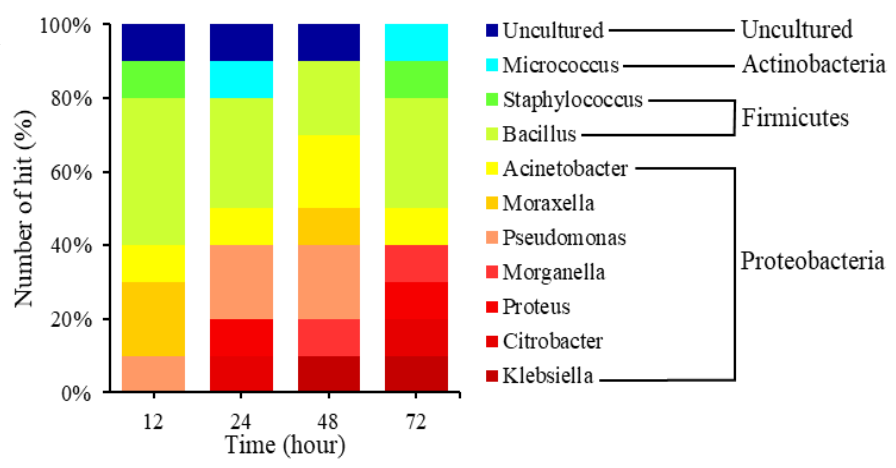

Figure 3. Relative abundance of lipolytic bacteria associated with tempeh. Relative abundance of lipolytic bacteria from CMG (A); EMP (B); and RTI (C). Time in the graph shows the age of the tempeh where the lipolytic bacteria were successfully isolated 


\section{ACKNOWLEDGEMENTS}

This work was supported by Program Magister Doktor Sarjana Unggul (PMDSU) from Ministry of Research, Technology and Higher Education, Republic of Indonesia. The authors have no conflict of interest to declare.

\section{REFERENCES}

Abdou AM. 2003. Purification and partial characterization of psychrotrophic Serratia marcescens lipase. J Dairy Sci 86 (1): 127 132. DOI: 10.3168/jds.S0022-0302(03)73591-7.

Astuti M, Meliala A, Dalais FS, Wahlqvist ML. 2000. Tempe, a nutritious and healthy food from Indonesia. Asia Pac J Clin Nutr 9 (4): 322-325. DOI: 10.1046/j.1440-6047.2000.00176x.

Babu PD, Bhakyaraj R, Vidhyalakshmi R. 2009. A low cost nutritious food "Tempeh" - a review. World J Dairy Food Sci 4 (1): 22-27.

Barus T, Suwanto A, Wahyudi AT, Wijaya H. 2008. Role of bacteria in tempe bitter taste formation microbiological and molecular biological analysis based on 16S rRNA gene. Microbiol Indon 2 (1): 17-21 DOI: $10.5454 / \mathrm{mi} .2 .1 .4$

Cappuccino JG, Sherman N. 2001. Microbiology A Laboratory Manual. Benjamin Cummings, New York

Carvalho SM, Mendonça MA, Pinho DMM, Resck IS, Suarez PAZ. 2012. Chromatographic analyses of fatty acid methyl esters by HPLC-UV and GC-FID. J Braz Chem Soc 23 (4): 763-769. DOI: 10.1590/S0103-50532012000400023.

Christen P, López-Munguía A. 2009. Enzymes and food flavor-A review. $\begin{array}{lllll}\text { Food Biotechnol } & 8 & (2-3): & 167-190 . & \text { DOI }\end{array}$ 10.1080/08905439409549874.

Feller G, Thiry M, Gerday C. 1991. Nucleotide sequence of the lipase gene lip2 from the antarctic psychrotroph Moraxella TA144 and sitespecific mutagenesis of the conserved serine and histidine residues. DNA Cell Biol 10 (5): 381-388. DOI: 10.1089/dna.1991.10.381.

Fox PF, Guinee TP, Cogan TM, McSweeney PLH. 2000. Fundamentals of Cheese Science. Aspen Publishers Inc, Gaithersburg.

Fox PF, Wallace JM. 1997. Formation of flavour compounds in cheese. Advan App Microbiol 45: 17-85. DOI: 10.1016/s00652164(08)70261-2.

Gunasekaran V, Kotay SM, Das D. 2006. Alkaline lipase production by Citrobacter freundii IIT-BT L139. Indian J Exp Biol 44 (6): 485-491.

Gunawan-Puteri MDPT, Hassanein TR, Prabawati EK, Wijaya $\mathrm{CH}$, Mutukumira AN. 2015. Sensory characteristics of seasoning powders from overripe tempeh, a solid state fermented soybean. Proc Chem 14: 263-269. DOI: 10.1016/j.proche.2015.03.037.

Hagedorn S, Kaphammer B. 1994. Microbial biocatalysis in the generation of flavor and fragrance chemical. Ann Rev Microbiol 48: 773-800. DOI: 10.1146/annurev.mi.48.100194.004013.

Hassanein TR, Prabawati EK, Gunawan-Puteri MDPT. 2015. Analysis of chemical and microbial changes during storage of overripe tempeh powder as seasoning material. Intl J Sci Eng 8 (2): 131-134. DOI 10.12777/ijse.8.2.131-134.
Jarvis GN, Strömpl C, Moore ERB, Thiele JH. 1997. Isolation and characterisation of obligately anaerobic, lipolytic bacteria from the rumen of red deer. Syst Appl Microbiol 21 (1): 135-43. DOI: 10.1016/S0723-2020(98)80017-9.

Keuth S, Bisping B. 1994. Vitamin B 12 production by Citrobacter freundii or Klebsiella pneumonia during tempeh fermentation and proof of enterotoxin absence by PCR. Appl Environ Microbiol 60 (5): 14951499

Klus K, Borger-Papendorf G, Barz W. 1993. Formation of 6,7,4 tryhidroxyisoflavone (factor 2) from soybean seed isoflavone by bacteria isolated from tempe. J Phytochem 34: 979-981.

Korman TP, Bowie JU. 2012. Crystal Structure of Proteus mirabilis Lipase, a Novel lipase from the proteus/psychrophilic subfamily of lipase family I. 1. PLoS ONE 7 (12): e52890. DOI: 10.1371/journal.pone.0052890.

Kouker G, Jaeger KE. 1987. Specific and sensitive plate assay for bacterial lipases. Appl Environ Microbiol 53: 211-213.

Kumar D, Kumar L, Nagar S, Raina C, Parshad R, Gupta VK. 2012a. Screening, isolation, and production of lipase/esterase producing Bacillus sp. strain DVL 2 and its potential evaluation in esterification and resolution reactions. Arc App Sci Res.4 (4): 1763-1770.

Leitao MFF, Menezes TJB, Tango JS. 1967. Production of tempeh-a fermented soy product. Coletanea do Instituto de Tecnologia de Alimentos Campinas 2: 333-339.

Marchesi JR, Sato T, Weightman AJ, Martin TA, Fry JC, Hiom SJ, Wade WG. 1998. Design and evaluation of useful bacterium-specific PCR primers that amplify genes coding for bacterial $16 \mathrm{~S}$ rRNA. Appl Environ Microbiol 64 (2): 795-799.

McSweeney PLH, Sousa MJ. 2000. Biochemical pathways for the production of flavour compounds in cheeses during ripening: A review. Le Lait 80: 293-324. DOI: 10.1051/lait:2000127.

Mienda BS, Idi A, Umar A. 2011. Microbiological features of solid-state fermentation and its applications-an overview. Res Biotechnol 2 (6): 21-26.

Nawar WW. 1996. Lipids. In: Fennema OR (eds.). Food Chemistry, 3rd ed. Marcel Dekker in, New York.

Olivares A, Navvaro JL, Flores M. 2011. Effect of fat content on aroma generation during processing of dry fermented sausages. Meat Sci 87: 264-273. DOI: 10.1016/j.meatsci.2010.10.021

Ritvanen T, Lampolahti S, Lilleberg L, Tupasela T, Isoniemi M, Appelbye U, Lyytikainen T, Eerola S, Uusi-Rauva E. 2005. Sensory evaluation, chemical composition and consumer acceptance of full fat and reduced-fat cheeses in the Finnish market. Food Qual Pref 16: 479492. DOI: 10.1016/j.foodqual.2004.10.001.

Shurtleff W, Aoyagi A. 1979. The Book of Tempeh, A Cultured Soyfood, second edition. Ten Speed Press, California.

Snellman EA, Sullivan ER, Colwell RR. 2002. Purification and properties of the extracellular lipase, LipA, of Acinetobacter sp. RAG-1. Eur J Biochem 269 (23): 5771-5779. DOI: 10.1046/j.14321033.2002.03235x.

Utami R, Wijaya CH, Lioe HN. 2015. Taste of water-soluble extracts obtained from over-fermented tempe. Intl J Food Prop 19 (9): 20632073. DOI: 10.1080/10942912.2015.1104509.

Woodman ME, Savage CR, Arnold WK, Stevenson B. 2016. Direct PCR of intact bacteria (Colony PCR). Curr Protoc Microbiol 42: A.3D.1 A.3D.7. DOI:10.1002/cpmc.14. 